\title{
Evaluating the Potential for Near-Shore Bathymetry on the Majuro Atoll, Republic of the Marshall Islands, Using Landsat 8 and WorldView-3 Imagery
}

Scientific Investigations Report 2018-5024

U.S. Department of the Interior

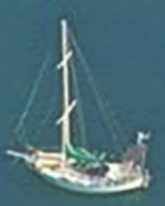

U.S. Geological Survey

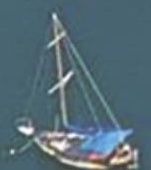


Cover. Majuro, Majuro Atoll, Republic of the Marshall Islands, surrounded by the shallow lagoon (foreground) and the deep Pacific Ocean (background). Image taken by Maria Kottermair, Geospatial Coordinator, Pacific Islands Climate Science Center at the University of Guam. 


\section{Evaluating the Potential for Near-Shore Bathymetry on the Majuro Atoll, Republic of the Marshall Islands, Using Landsat 8 and WorldView-3 Imagery}

By Sandra K. Poppenga, Monica Palaseanu-Lovejoy, Dean B. Gesch, Jeffrey J.

Danielson, and Dean J. Tyler

Scientific Investigations Report 2018-5024 


\title{
U.S. Department of the Interior \\ RYAN K. ZINKE, Secretary
}

\section{U.S. Geological Survey William H. Werkheiser, Deputy Director exercising the authority of the Director}

\author{
U.S. Geological Survey, Reston, Virginia: 2018
}

For more information on the USGS - the Federal source for science about the Earth, its natural and living resources, natural hazards, and the environment-visit https://www.usgs.gov or call 1-888-ASK-USGS.

For an overview of USGS information products, including maps, imagery, and publications, visit https://store.usgs.gov.

Any use of trade, firm, or product names is for descriptive purposes only and does not imply endorsement by the U.S. Government.

Although this information product, for the most part, is in the public domain, it also may contain copyrighted materials as noted in the text. Permission to reproduce copyrighted items must be secured from the copyright owner.

Suggested citation:

Poppenga, S.K., Palaseanu-Lovejoy, M., Gesch, D.B., Danielson, J.J., and Tyler, D.J., 2018, Evaluating the potential for near-shore bathymetry on the Majuro Atoll, Republic of the Marshall Islands, using Landsat 8 and WorldView-3 imagery: U.S. Geological Survey Scientific Investigations Report 2018-5024, 14 p., https://doi.org/10.3133/sir20185024.

ISSN 2328-0328 (online) 


\section{Acknowledgments}

This research was completed in collaboration with the Department of Interior (DOI) Pacific Islands Climate Science Center (PI-CSC), the U.S. Geological Survey (USGS) Coastal and Marine Geology Program (CMGP), and the USGS Coastal National Elevation Database (CoNED) Applications Project. The authors thank David Helweg, Ph.D., Director, DOI PI-CSC; John Haines, Ph.D., Program Coordinator, USGS CMGP; the U.S. Naval Oceanographic Office for the CHARTS bathymetric lidar data; Clinton Behrns, Maritime Safety Office, NGA, for access to nautical charts; Tony Kimmet, U.S. Department of Agriculture Natural Resources Conservation Services (USDA-NRCS) National Geospatial Center of Excellence for providing DigitalGlobe WorldView-3 satellite imagery; and Gregory Miecznik, DigitalGlobe. The authors also are grateful to Shachak Pe'eri, Ph.D., National Oceanic and Atmospheric Administration (NOAA) Office of Coast Survey, and Christopher Parrish, Ph.D., Oregon State University, for their satellite-derived bathymetry expertise. 



\section{Contents}

Acknowledgments ……...................................................................................................................

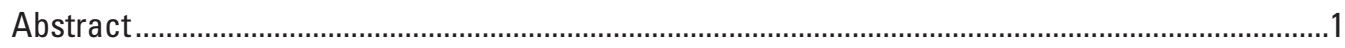

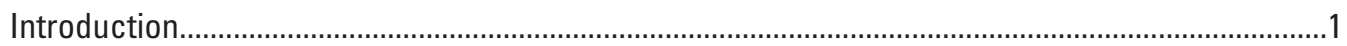

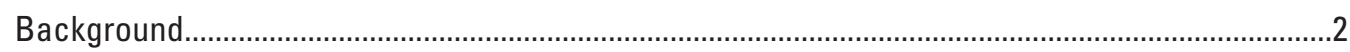

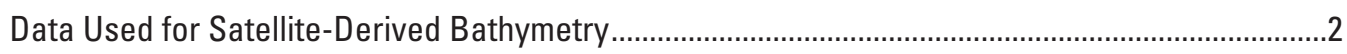

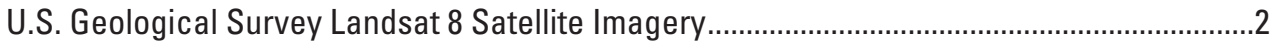

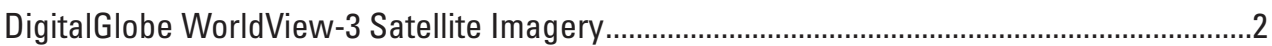

Compact Hydrographic Airborne Rapid Total Survey Bathymetric Lidar ..................................4

National Geospatial-Intelligence Agency Nautical Charts ......................................................

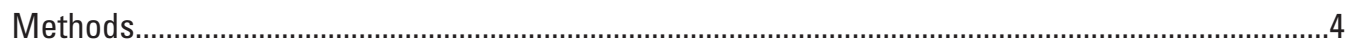

Satellite-Derived Bathymetry Vertical Profile Estimates ...........................................................

Calibration of Vertical Profile Estimates ..................................................................................

Validation of Vertical Profile Estimates .......................................................................................

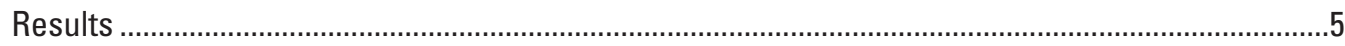

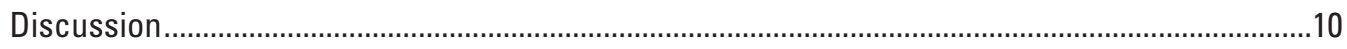

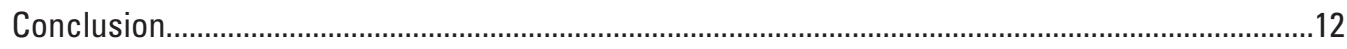

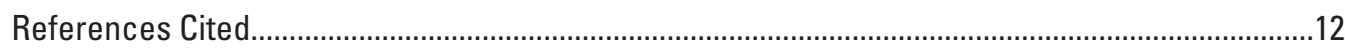

\section{Figures}

1. Image showing Majuro Atoll, Republic of the Marshall Islands .........................................

2. Image showing areas of Compact Hydrographic Airborne Rapid Total Survey bathymetric light detection and ranging calibration and validation data ..........................

3. Image showing medium- and high-resolution satellite-derived bathymetry for the Majuro Atoll, Republic of the Marshall Islands .................................................................

4. Split violin plots showing satellite-derived bathymetry validation errors in meters compared to the Compact Hydrographic Airborne Rapid Total Survey data .....................

5. Image showing satellite-derived bathymetry integrated into the Majuro Atoll, Republic of the Marshall Islands, topobathymetric digital elevation model ....................11

\section{Tables}

1. Validation measurement results for satellite-derived bathymetry estimates and Compact Hydrographic Airborne Rapid Total Survey bathymetric light detection and ranging data .........................................................................................

2. Error metrics for the satellite-derived bathymetry accuracy assessments .....................8 


\section{Conversion Factors}

International System of Units to U.S. customary units

\begin{tabular}{|c|c|c|}
\hline Multiply & By & To obtain \\
\hline \multicolumn{3}{|c|}{ Length } \\
\hline meter $(\mathrm{m})$ & 3.281 & U.S. Survey foot (ft) \\
\hline meter (m) & $1 / 0.3048$ & international foot $(\mathrm{ft})$ \\
\hline meter $(\mathrm{m})$ & 1.094 & yard (yd) \\
\hline kilometer (km) & 0.621 & mile (mi) \\
\hline
\end{tabular}

\section{Datum}

Horizontal coordinate system is Universal Transverse Mercator (UTM) Zone 59 North referenced to International Terrestrial Reference Frame 2008 (ITRF2008).

Vertical datum is referenced to Local Mean Sea Level (LMSL).

\section{Abbreviations}

$\begin{array}{ll}\text { ACOMP } & \text { atmospherically corrected } \\ \text { CHARTS } & \text { Compact Hydrographic Airborne Rapid Total Survey } \\ \text { CMGP } & \text { Coastal and Marine Geology Program } \\ \text { CoNED } & \text { Coastal National Elevation Database } \\ \text { DNC } & \text { Digital Nautical Chart } \\ \text { DOI } & \text { Department of the Interior } \\ \text { L8 } & \text { Landsat 8 } \\ \text { lidar } & \text { light detection and ranging } \\ \text { LMSL } & \text { local mean sea level } \\ \text { ME } & \text { mean error } \\ \text { MLWS } & \text { mean low water springs } \\ \text { NAVOCEANO } & \text { Naval Oceanographic Office } \\ \text { NGA } & \text { National Geospatial-Intelligence Agency } \\ \text { NOAA } & \text { National Oceanic and Atmospheric Administration } \\ \text { NIR } & \text { near-infrared } \\ \text { PI-CSC } & \text { Pacific Islands Climate Science Center } \\ \text { RMSE } & \text { root mean square error } \\ \text { SDB } & \text { satellite-derived bathymetry } \\ \text { SfM } & \text { Structure from Motion }\end{array}$


SOPAC South Pacific Applied Geoscience Commission

SWIR shortwave infrared

TBDEM topobathymetric digital elevation model

UAS Unmanned Aircraft Systems

USGS U.S. Geological Survey

UTM Universal Transverse Mercator

VPF Vector Product Format

WV-3 WorldView-3 



\title{
Evaluating the Potential for Near-Shore Bathymetry on the Majuro Atoll, Republic of the Marshall Islands, Using Landsat 8 and WorldView-3 Imagery
}

\author{
By Sandra K. Poppenga, Monica Palaseanu-Lovejoy, Dean B. Gesch, Jeffrey J. Danielson, and Dean J. Tyler
}

\section{Abstract}

Satellite-derived near-shore bathymetry (SDB) is becoming an increasingly important method for assessing vulnerability to climate change and natural hazards in lowlying atolls of the northern tropical Pacific Ocean. Satellite imagery has become a cost-effective means for mapping near-shore bathymetry because ships cannot collect soundings safely while operating close to the shore. Also, green laser light detection and ranging (lidar) acquisitions are expensive in remote locations. Previous research has demonstrated that spectral band ratio-based techniques, commonly called the natural logarithm approach, may lead to more precise measurements and modeling of bathymetry because of the phenomenon that different substrates at the same depth have approximately equal ratio values. The goal of this research was to apply the band ratio technique to Landsat 8 at-sensor radiance imagery and WorldView-3 atmospherically corrected imagery in the coastal waters surrounding the Majuro Atoll, Republic of the Marshall Islands, to derive near-shore bathymetry that could be incorporated into a seamless topobathymetric digital elevation model of Majuro. Attenuation of light within the water column was characterized by measuring at-sensor radiance and reflectance at different depths and calculating an attenuation coefficient. Bathymetric lidar data, collected by the U.S. Naval Oceanographic Office in 2006, were used to calibrate the SDB results. The bathymetric lidar yielded a strong linear relation with water depths. The Landsat 8-derived SDB estimates derived from the blue/green band ratio exhibited a water attenuation extinction depth of 6 meters with a coefficient of determination $R^{2}=0.9324$. Estimates derived from the coastal/red band ratio had an $R^{2}=0.9597$. At the same extinction depth, SDB estimates derived from WorldView-3 imagery exhibited an $R^{2}=0.9574$. Because highly dynamic coastal shorelines can be affected by erosion, wetland loss, hurricanes, sea-level rise, urban development, and population growth, consistent bathymetric data are needed to better understand sensitive coastal land/water interfaces in areas subject to coastal disasters.

\section{Introduction}

Satellite-derived near-shore bathymetry (SDB) remote sensing research uses ocean optics to estimate near-shore bathymetry using passive multispectral satellite imagery, such as Landsat 8 (L8) or DigitalGlobe WorldView-3 (WV-3) (Gesch and others, 2016; Pe'eri and others, 2014; 2016a; 2016b; Stumpf and others, 2003). Active sensors, such as light detection and ranging (lidar) or sound navigation and ranging (sonar), have been used to collect bathymetric data; however, mapping islands in the Pacific Ocean with green laser lidar sensors aboard a small, fixed-wing aircraft is expensive. Because surface vessels often cannot collect soundings safely while operating close to the shore, satellite imagery has potential to be a more cost-effective means for mapping near-shore bathymetry to assess vulnerability to natural hazards in lowlying atolls in the northern tropical Pacific.

In the scientific literature, the most common method used to derive bathymetry from satellite imagery is an optimization approach using spectral band ratio-based techniques, more commonly called the ratio of natural logarithm approach (Dierssen and others, 2003; International Hydrographic Organization, Intergovernmental Oceanographic Commission, 2016; Pe'eri and others, 2014; 2016a; 2016b; Stumpf and others, 2003). This empirical method may lead to more precise measurements and modeling of bathymetry because different substrates at the same depth have approximately equal ratio values (Legleiter and Overstreet, 2012). A study by Pe'eri and others (2014) indicated that, based on the assumption that the water column is uniformly mixed, the ratio of two bands, such as blue/green, will maintain a near-constant attenuation value that is the difference of the diffuse attenuation coefficient values at two different wavelengths. The concept underlying the ratio transform approach is that bottom radiance of one band will decay faster with depth as compared to the other band. As a result, the ratio between the two bands will vary with depth (Pe'eri and others, 2014). The logarithm of the band-ratio approach accounts for the exponential attenuation of light in the water column; therefore, the image-derived quantity, or the change in ratio between bands, is affected more by depth 
than by bottom reflectance (Stumpf and others, 2003). Thus, a linear relation between water depth and reflectance, relative radiance, or raw digital numbers in one or more spectral bands is commonly used for SDB (Legleiter and others, 2012; Pe'eri and others, 2014; 2016a; 2016b).

According to Stumpf and others (2003), the use of satellite imagery might be the only viable way to synoptically characterize either extensive or remote coral reef environments because of incomplete or spatially limited bathymetric data or difficulty obtaining soundings in remote reef areas. Stumpf and others (2003) indicated that high spatial resolution is required due to the relatively small horizontal spatial features in remote coral atoll locations; therefore, medium resolution (30 meters $[\mathrm{m}])$ and high-resolution $(1.6 \mathrm{~m})$ satellite imagery were used to estimate SDB for the Majuro Atoll coral reef environment.

\section{Background}

In the northern tropical Pacific Ocean, Majuro is a large coral atoll consisting of a central narrow landmass and a set of small perimeter islets that are part of the Republic of the Marshall Islands (fig. 1). The Pacific Ocean on the exterior of the atoll and the lagoon within its interior consist of unconsolidated and consolidated carbonate sediment, steep slopes, and deep bathymetry. Information about the bathymetry of the shallow waters surrounding the coral atoll is not well known (Kruger and Kumar, 2008). This low-lying atoll is extremely vulnerable to sea-level rise, tsunamis, storm surge, and coastal flooding that could affect the sustainability of the infrastructure, groundwater, and ecosystems (Palaseanu-Lovejoy and others, 2017a; 2017b).

The highest natural elevation of the Majuro Atoll is estimated at only $3 \mathrm{~m}$ above sea level at the community of Laura on the western part of the atoll (fig. 1). The capital city of Majuro, on the eastern edge of the atoll, has the largest population. The island community of Djarrit is on the northeast part of the atoll. The lack of high-resolution topographic data has been identified as a critical data gap for climate vulnerability and adaptation efforts and for high-resolution inundation modeling for atoll nations (Helweg and others, 2014; Palaseanu-Lovejoy and others, 2017b). Therefore, nearshore bathymetry was derived from the best available L8 and WV-3 satellite imagery to integrate into a 1-m topobathymetric digital elevation model (TBDEM) for the Coastal National Elevation Database (CoNED) Majuro Atoll to support stormand tide-induced flood modeling (Danielson and others, 2016; Palaseanu-Lovejoy and others, 2017b; Thatcher and others, 2016). The Majuro TBDEM development was a collaboration among the U.S. Geological Survey (USGS) CoNED Applications Project, Department of the Interior (DOI) Pacific Islands Climate Science Center (PI-CSC), USGS Coastal and Marine Geology Program (CMGP), University of Guam, University of Hawaii at Mânoa, National Oceanic and Atmospheric
Administration (NOAA) National Geodetic Survey, the Republic of the Marshall Islands Office of Lands and Survey, College of the Marshall Islands, Directorate of Civil Aviation Republic of the Marshall Islands, and the Marshall Islands Conservation Society (Palaseanu-Lovejoy and others, 2017a; 2017b).

\section{Data Used for Satellite-Derived Bathymetry}

\section{U.S. Geological Survey Landsat 8 Satellite Imagery}

The L8 Operational Land Imager Level-1, 16-bit, relatively cloud-free multispectral imagery acquired at nadir on March 1, 2016, was downloaded from USGS EarthExplorer in georeferenced GeoTIFF format in Universal Transverse Mercator (UTM) Zone 59 North projection (U.S. Geological Survey, 2016b). The L8 satellite orbits the Earth at an altitude of 705 kilometers $(\mathrm{km})$ (438 miles [mi]). The satellite images a swath width of $185 \mathrm{~km}(115 \mathrm{mi})$ in a sun-synchronous, nearpolar orbit with a revisit frequency of 16 days (U.S. Geological Survey, 2016a). The multispectral bands used in the SDB process were coastal band $1(0.43-0.45$ micrometer $[\mu \mathrm{m}])$, blue band $2(0.45-0.51 \mu \mathrm{m})$, green band $3(0.53-0.59 \mu \mathrm{m})$, red band $4(0.64-0.67 \mu \mathrm{m})$, and the shortwave infrared (SWIR)-1 band $6(1.57-1.65 \mu \mathrm{m})$ (U.S. Geological Survey, 2016a). The Landsat satellites have continuously acquired space-based images of the Earth's land surface, providing data that serve as valuable resources for a number of applications; for example, the L8 Operational Land Imager contains a deep blue band for coastal areas and shallow water observations that is useful for SDB research (U.S. Geological Survey, 2016a).

\section{DigitaIGlobe WorldView-3 Satellite Imagery}

DigitalGlobe WV-3 Level-2A atmospherically corrected (ACOMP) over water, 16-bit, multispectral imagery acquired at $13.9^{\circ}$ mean off-nadir angle on March 30, 2016, was obtained from DigitalGlobe in georeferenced TIF format in UTM Zone 59 North projection (DigitalGlobe, 2016). The DigitalGlobe WV-3 satellite orbits the Earth at an expected altitude of $617 \mathrm{~km}$ (383 mi), imaging a swath width at nadir of $13.1 \mathrm{~km}(8 \mathrm{mi})$ with a revisit frequency of less than 1.0 day at $40^{\circ} \mathrm{N}$ latitude and 4.5 days at $20^{\circ}$ off nadir or less (DigitalGlobe, 2016). The multispectral bands used in the SDB process were blue band $2(0.45-0.51 \mu \mathrm{m})$, green band $3(0.51-0.58 \mu \mathrm{m})$, and the near-infrared (NIR2) band 8 $(0.86-1.04 \mu \mathrm{m})$. 


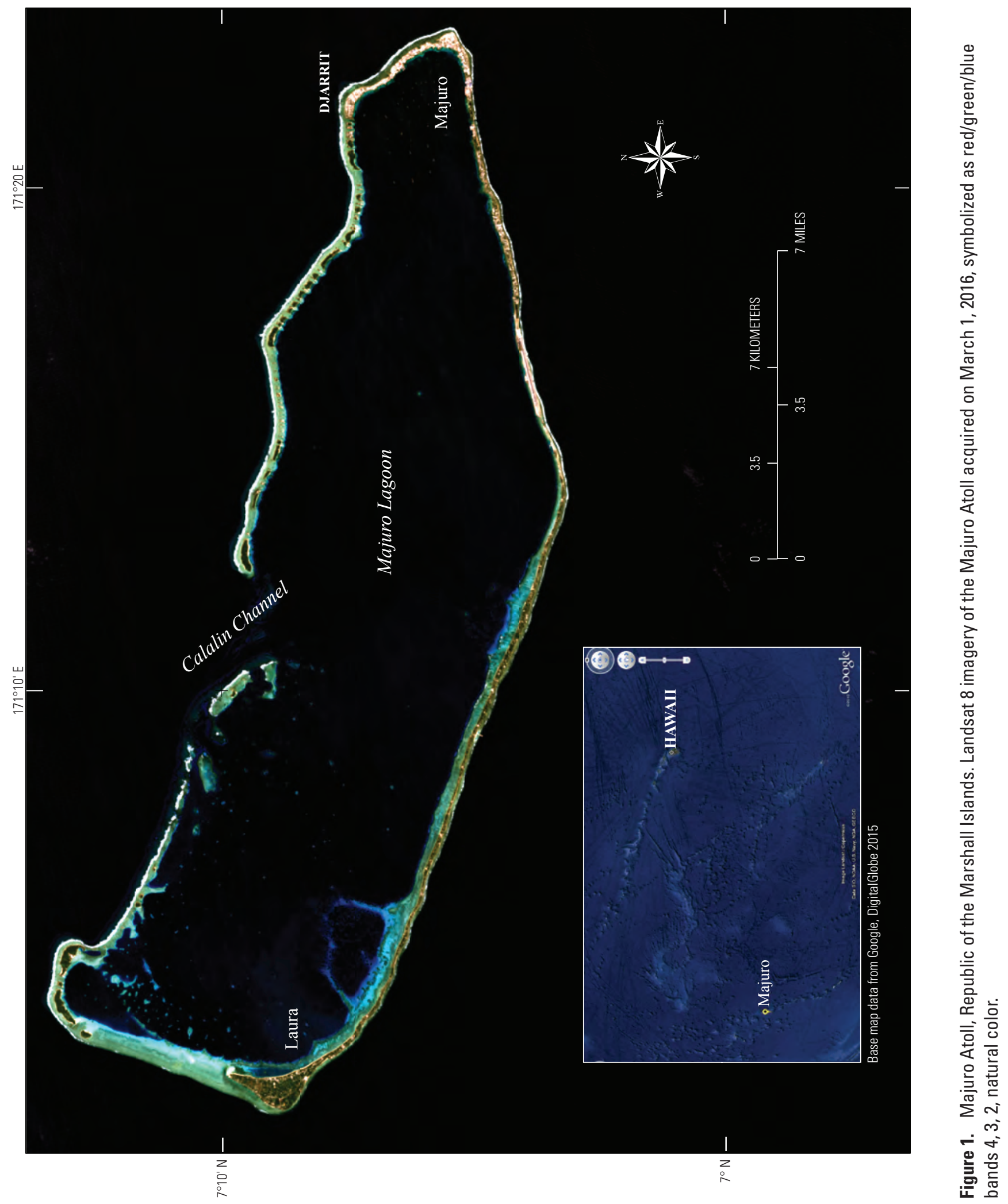




\section{Compact Hydrographic Airborne Rapid Total Survey Bathymetric Lidar}

An airborne hydrographic survey of the Majuro Calalin Channel, Republic of the Marshall Islands (fig. 1), was completed by the U.S. Naval Oceanographic Office (NAVOCEANO) on April 25, 2006, using the Compact Hydrographic Airborne Rapid Total Survey (CHARTS) aboard a Beachcraft King Air 200 at a wavelength of 532 nanometers (nm). All point data measurements were referenced to World Geodetic System 1984 (WGS84) ellipsoid in meters and vertically referenced to mean low water springs (MLWS) (Naval Oceanographic Office, 2006a, 2006b). According to the NAVOCEANO Report of Survey, the CHARTS system collects bathymetric lidar data that meet the U.S. Army Corps of Engineers survey standard of 30 centimeter $(\mathrm{cm})$ root mean square error (RMSE) (Naval Oceanographic Office, 2006b). The CHARTS bathymetric lidar data were obtained from NAVOCEANO to use as control points for SDB calibration (Naval Oceanographic Office, 2006a).

\section{National Geospatial-Intelligence Agency Nautical Charts}

The North Pacific Ocean Republic of the Marshall Islands Majuro Atoll Nautical Chart 81782 was obtained from the National Geospatial-Intelligence Agency (NGA) as a georeferenced .pdf (National Geospatial-Intelligence Agency Maritime Safety Office, 2011) and was converted to a georeferenced .tiff (raster format) to use as reference information in a geographic information system. Additionally, the Digital Nautical Chart (DNC) 12 Library for the Majuro Atoll was obtained from NGA as Vector Product Format (VPF) that contained hydrographic sounding feature classes (National GeospatialIntelligence Agency Maritime Safety Office, 2017). The

DNC 12 VPF soundings were from U.S. Navy surveys of 1944 and 2006 (National Geospatial-Intelligence Agency Maritime Safety Office, 2011; 2017) and were initially used for reference information and for SDB calibration testing.

\section{Methods}

\section{Satellite-Derived Bathymetry Vertical Profile Estimates}

The band ratio technique (Dierssen and others, 2003; International Hydrographic Organization, 2016; Pe'eri and others, 2014; 2016a; 2016b) was applied to L8 at-sensor radiance imagery and WV-3 ACOMP imagery in the coastal waters surrounding the Majuro Atoll, Republic of the Marshall Islands. Esri ArcMap and Harris Geospatial ENVI software were used to subset and process the L8 and WV-3 imagery to the Majuro Atoll extent. The L8 and WV-3 raw imagery values were converted to floating point values. An inflection point was determined on a spectral response curve between the land and water using the L8 SWIR-1 band $6(1.57-1.65 \mu \mathrm{m})$ and WV-3 NIR2 band $8(0.86-1.04 \mu \mathrm{m})$ to mask out the land part of the study area. The WV-3 SWIR-1 band at 3.74-m resolution was not used to determine the inflection point in the WV-3 imagery because the resolution differed from the WV-3 multispectral bands at 1.6-m resolution. The WV-3 NIR2 band (8) was used instead because it had a similar wavelength as the L8 SWIR-1 band (6).

Attenuation of light within the water column was characterized by measuring at-sensor radiance or reflectance at different depths and calculating an attenuation coefficient based on the ratio of L8 bands blue (2)/green (3) and L8 bands coastal (1)/red (4). The WV-3 SDB attenuation coefficient was based on the blue (2)/green (3) band ratio (eq. 1). The concept underlying the ratio transform approach is that bottom radiance of one band will decay faster with depth than the other band. As a result, the ratio between the two bands will vary with depth (Pe'eri and others, 2014).

This ratio of natural logarithms method, as shown in equation 1, calculates relative vertical profile estimates using multispectral satellite bands from which the diffuse attenuation coefficients are computed (Dierssen and others, 2003; Pe'eri and others, 2014; Stumpf and others, 2003). Depth estimates are derived using this equation as in the Stumpf and Pe'eri approach:

$$
z=m_{1}\left(\frac{\ln \left(L_{o b s}\left(\lambda_{i}\right)\right)}{\ln \left(L_{o b s}\left(\lambda_{j}\right)\right)}\right)-m_{0}
$$

where

$$
\begin{aligned}
& m_{1} \text { and } m_{0} \begin{array}{c}
\text { is the relative vertical profile depth estimates, } \\
\text { are the gain (tangent of the slope angle) and } \\
\text { offset (intercept), respectively, that are } \\
\text { empirically determined, }
\end{array} \\
& \text { in } \quad \begin{array}{r}
\text { is the natural logarithm ratio of the attenuation } \\
\text { between observed radiance estimated } \\
\text { (reflectance for WV-3 ACOMP) }
\end{array} \\
& \begin{array}{l}
\text { observed radiance of the Landsat blue band or } \\
\text { observed reflectance of the WV-3 coastal } \\
\text { band, and }
\end{array} \\
& \begin{array}{l}
\text { observed radiance of the Landsat green band } \\
\text { or observed reflectance of the WV-3 red } \\
\text { band. }
\end{array}
\end{aligned}
$$

The resulting values represent relative SDB vertical profile estimates that needed to be calibrated to obtain actual depth values.

\section{Calibration of Vertical Profile Estimates}

The CHARTS bathymetric lidar points were projected to UTM Zone 59 North projection. A linear regression was completed between the projected CHARTS bathymetric lidar 
values and the relative vertical profile estimates to derive an optical depth for inferring bathymetry, or extinction depth; an $R$-squared; and the regression line equation, which was applied to the relative vertical profiles estimates for calibration purposes. Optically deep values beyond the extinction depth then were removed.

Because the goal of this research was to generate nearshore SDB that could be integrated into a 1-m TBDEM (Danielson and others, 2016), the calibrated vertical profile SDB estimates were adjusted from chart or bathymetric lidar values (MLWS) to map datum (Local Mean Sea Level [LMSL]) by applying an adjustment value of $1.022 \mathrm{~m}$ derived from the Majuro International Airport benchmark tied to the local tidal benchmark (Naval Oceanographic Office, 2006a; 2006b). This adjustment was applied to achieve a consistent datum with topographic elevation data that are part of the CoNED Majuro Atoll TBDEM.

\section{Validation of Vertical Profile Estimates}

This research investigated the potential for using medium- and high-resolution satellite imagery (L8 and WV-3) to derive near-shore bathymetry for the Majuro Atoll, Republic of the Marshall Islands. The ratio of natural logarithms methodology required ancillary bathymetric data to calibrate the SDB estimates (Pe'eri and others, 2016a). The only available CHARTS bathymetric lidar data were collected in the Calalin Channel (Naval Oceanographic Office, 2006a; 2006b), a shipping channel in the northern part of the Majuro Atoll (fig. 1); therefore, part of the CHARTS bathymetric lidar data was used to calibrate the SDB estimates, and the remaining bathymetric lidar data were used for validation purposes (fig. 2).

Because the CHARTS bathymetric lidar data were available only in the upper-middle part of the atoll shipping channel, high-resolution (WV-3) SDB profiles were derived in this location to determine SDB profiles from atmospherically corrected satellite imagery over water using the ratio of natural logarithm approach.

The position errors between the measured values (CHARTS bathymetric lidar) and the estimated vertical profile $\mathrm{SDB}$ values were described using the mean error (ME), mean absolute error, standard deviation, and RMSE. The L8-derived SDB was validated against more than 16,000 bathymetric lidar points, and the WV-3-derived SDB was verified by more than 9,000 bathymetric lidar points.

\section{Results}

The calibrated SDB vertical profile estimates are shown in figure 3. The WV-3 blue/green ratio SDB results, shown in the central part of the Majuro Atoll, are derived from the only location where satellite imagery was atmospherically corrected over water (fig. 3, green). For the remaining part of the atoll, the blue/green ratio was applied to medium-resolution satellite imagery (L8) (fig. 3, red and light blue). In the western part of the atoll, the blue/green ratio SDB results were less than optimal because of very shallow reef flats. Therefore, the coastal/ red ratio was applied, which resulted in reasonable near-shore bathymetric estimates (fig. 3, light blue).

Position errors between the measured values (CHARTS bathymetric lidar) and the estimated vertical profile SDB are shown in table 1. There is a positive bias in the SDB data of $0.947 \mathrm{~m}$ (mean error) for the L8 blue/green band ratio SDB, $0.285 \mathrm{~m}$ for the $\mathrm{L} 8$ coastal/red band ratio, and $0.867 \mathrm{~m}$ for the WV-3-derived SDB (table 1). The L8 blue/green ratio was used to derive near-shore bathymetry for most of the atoll lagoon excluding depth values below the 6-m extinction depth. The L8 coastal/red ratio was better suited to derive near-shore bathymetry north of Laura because of the very shallow reef flats, and the WV-3 blue/green ratio was used to derive nearshore bathymetry for the central part of the atoll near the Calalin Channel (fig. 1) (Palaseanu-Lovejoy and others, 2017b).

For bathymetry in general, the vertical accuracy depends on water depth, water conditions, such as waves, tide, and water transparency, errors introduced by the instrument and the mode of deployment, cloud cover, atmospheric conditions, and the angle off nadir (Goodman and others, 2008; Lee, 2012; Pe'eri and others, 2014; 2016b). All these potential sources of errors may contribute to the positive bias in the SDB. The SDB data were split into two depth intervals, 0-4 m and 4-6 m (SDB extinction depth) (table 2), so the depth errors could be further investigated.

For L8 (blue/green and coastal/red ratios) and WV-3 (blue/green ratio) SDB, the ME for depths up to $4 \mathrm{~m}$ are $-0.199,-0.913$, and $1.253 \mathrm{~m}$, respectively, whereas the ME for depths greater than $4 \mathrm{~m}$ up to the optical extinction depth are $1.004,0.336$, and $0.810 \mathrm{~m}$, respectively. These results indicate bias in both depth interval data, but also that L8-derived SDB has a bimodal distribution as shown in the violin plot in figure 4.

A violin plot is, to a large extent, a box plot that incorporates information about the underlying distribution of the data, adding a rotated kernel density plot on each side (Hintze and Nelson, 1998; National Institute of Standards and Technology, 2015). In comparison, a box plot shows only summary statistics such as mean/median and interquartile ranges, whereas the violin plot shows the full distribution of the data. The difference is particularly useful when the data distribution is multimodal, such as for L8 data. A split violin plot shows two different groupings for a certain category. In this study, for each satellite sensor and band ratio (L8 blue/green, L8 coastal/ red, and WV-3 blue/green), the split violin plot shows the density distributions, box plots, and outliers of validation errors by depth (deep, from -6 to $-4 \mathrm{~m}$; and shallow, from -4 to $0 \mathrm{~m}$ ) (fig. 4). The data distribution shows a conspicuous bimodality in the L8 data, with positive bias for deeper waters ( -6 to $-4 \mathrm{~m})$ and negative bias for shallow waters ( -4 to $0 \mathrm{~m}$ ), whereas WV-3 data are positively biased in both depth categories.

This is one of the first attempts to use SDB for shallow near-shore bathymetry in the context of a tropical carbonate 


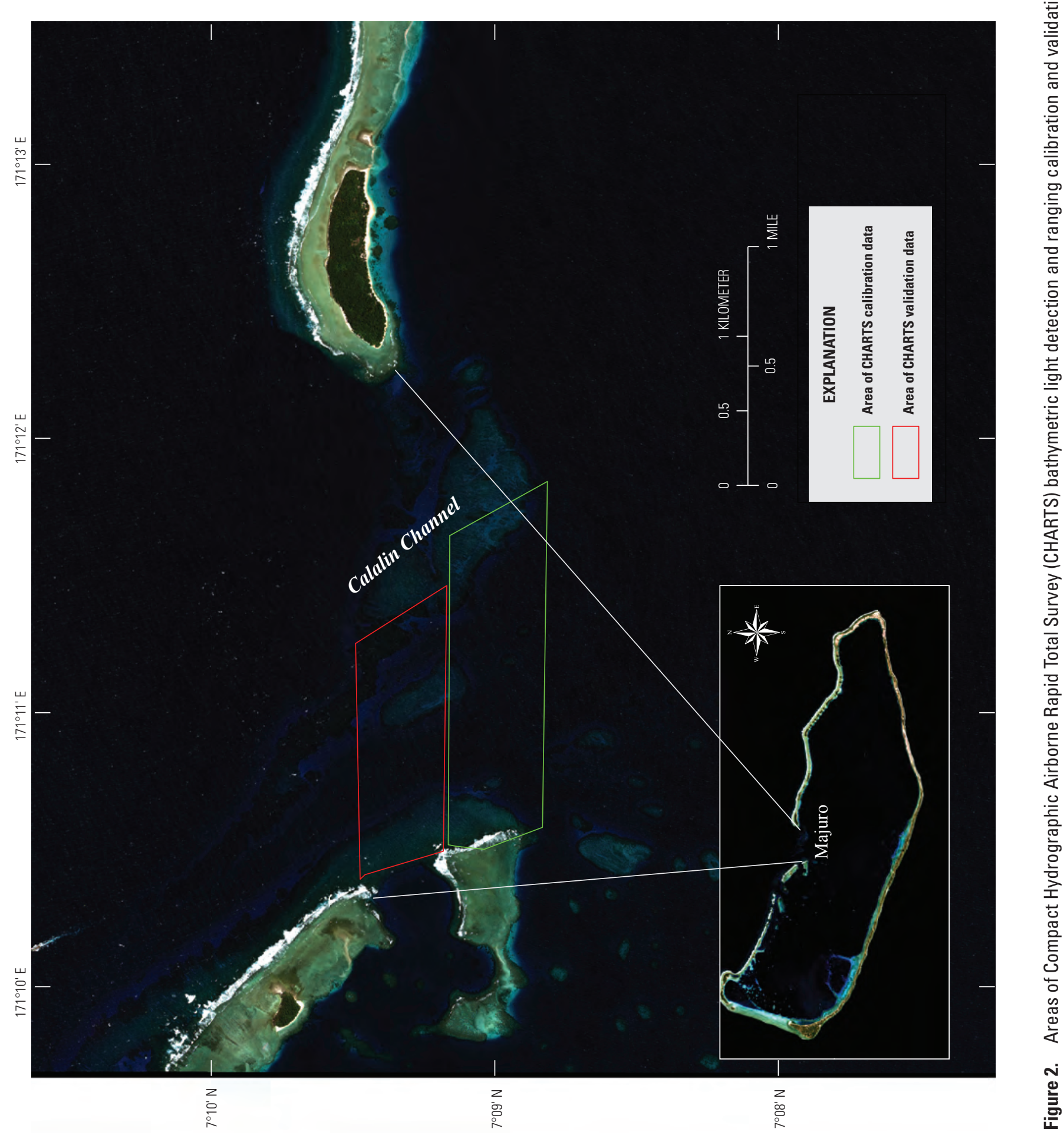




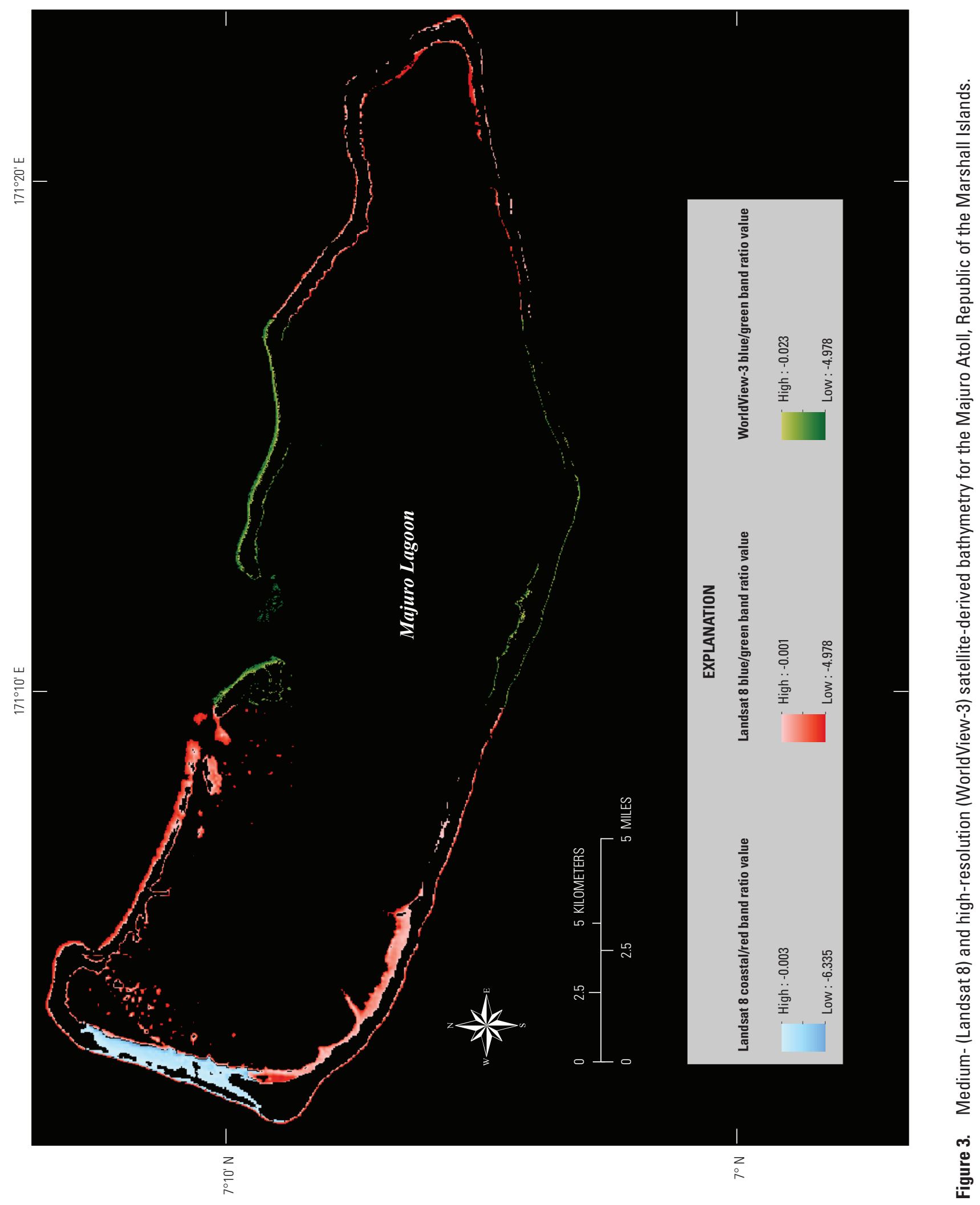


Table 1. Validation measurement results for satellite-derived bathymetry (SDB) estimates and Compact Hydrographic Airborne Rapid Total Survey (CHARTS) bathymetric light detection and ranging (lidar) data.

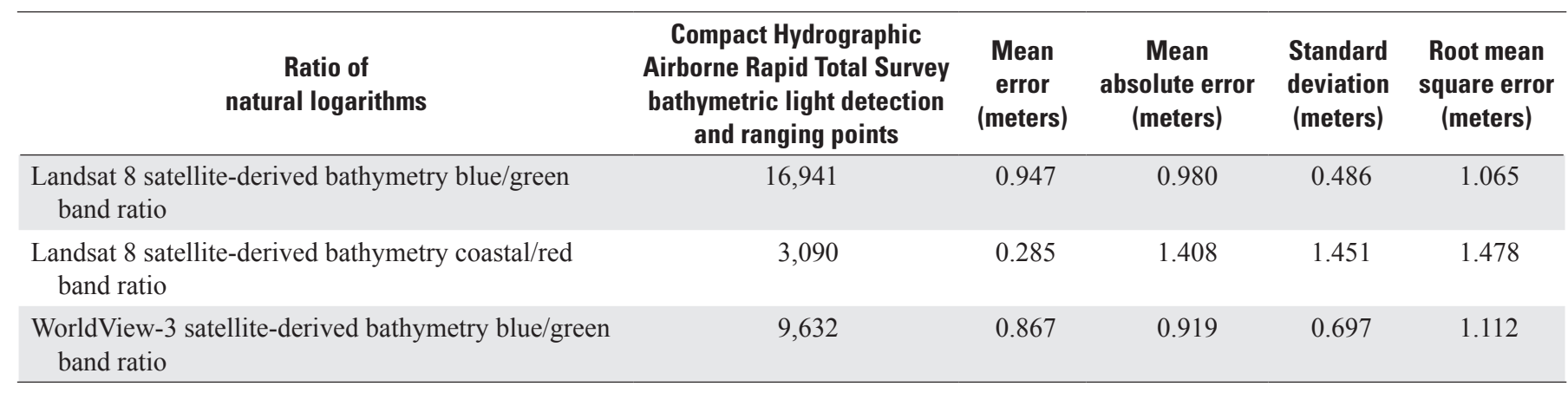

Table 2. Error metrics for the satellite-derived bathymetry (SDB) accuracy assessments.

\begin{tabular}{|c|c|c|c|c|}
\hline Depth & $\begin{array}{c}\text { Errors compared to Compact Hydrographic Airborne } \\
\text { Rapid Total Survey bathymetric light detection and } \\
\text { ranging }\end{array}$ & $\begin{array}{l}\text { Landsat } 8 \text { satellite- } \\
\text { derived bathymetry } \\
\text { blue/green ratio } \\
\text { (nadir) }\end{array}$ & $\begin{array}{l}\text { Landsat } 8 \text { satellite- } \\
\text { derived bathymetry } \\
\text { coastal/red ratio } \\
\text { (nadir) }\end{array}$ & $\begin{array}{l}\text { WorldView-3 satellite- } \\
\text { derived bathymetry } \\
\text { blue/green ratio } \\
\text { (off-nadir-view angle } \\
13.9 \text { degrees) }\end{array}$ \\
\hline \multirow[t]{3}{*}{ Overall } & $\begin{array}{l}\text { Compact Hydrographic Airborne Rapid Total Survey } \\
\text { bathymetric light detection and ranging points }\end{array}$ & 16,941 & 3,090 & 9,632 \\
\hline & Mean absolute error (meters) & 0.980 & 1.408 & 0.919 \\
\hline & Root mean square error (meters) & 1.065 & 1.478 & 1.112 \\
\hline $0-4 \mathrm{~m}$ & $\begin{array}{l}\text { Compact Hydrographic Airborne Rapid Total Survey } \\
\text { bathymetric light detection and ranging points }\end{array}$ & 801 & 125 & 1,239 \\
\hline \multirow[t]{4}{*}{$4-6 \mathrm{~m}$} & $\begin{array}{l}\text { Compact Hydrographic Airborne Rapid Total Survey } \\
\text { bathymetric light detection and ranging points }\end{array}$ & 16,140 & 2,965 & 8,393 \\
\hline & Mean error (meters) & 1.004 & 0.336 & 0.810 \\
\hline & Mean absolute error (meters) & 1.005 & 1.423 & 0.859 \\
\hline & Root mean square error (meters) & 1.082 & 1.488 & 1.011 \\
\hline
\end{tabular}




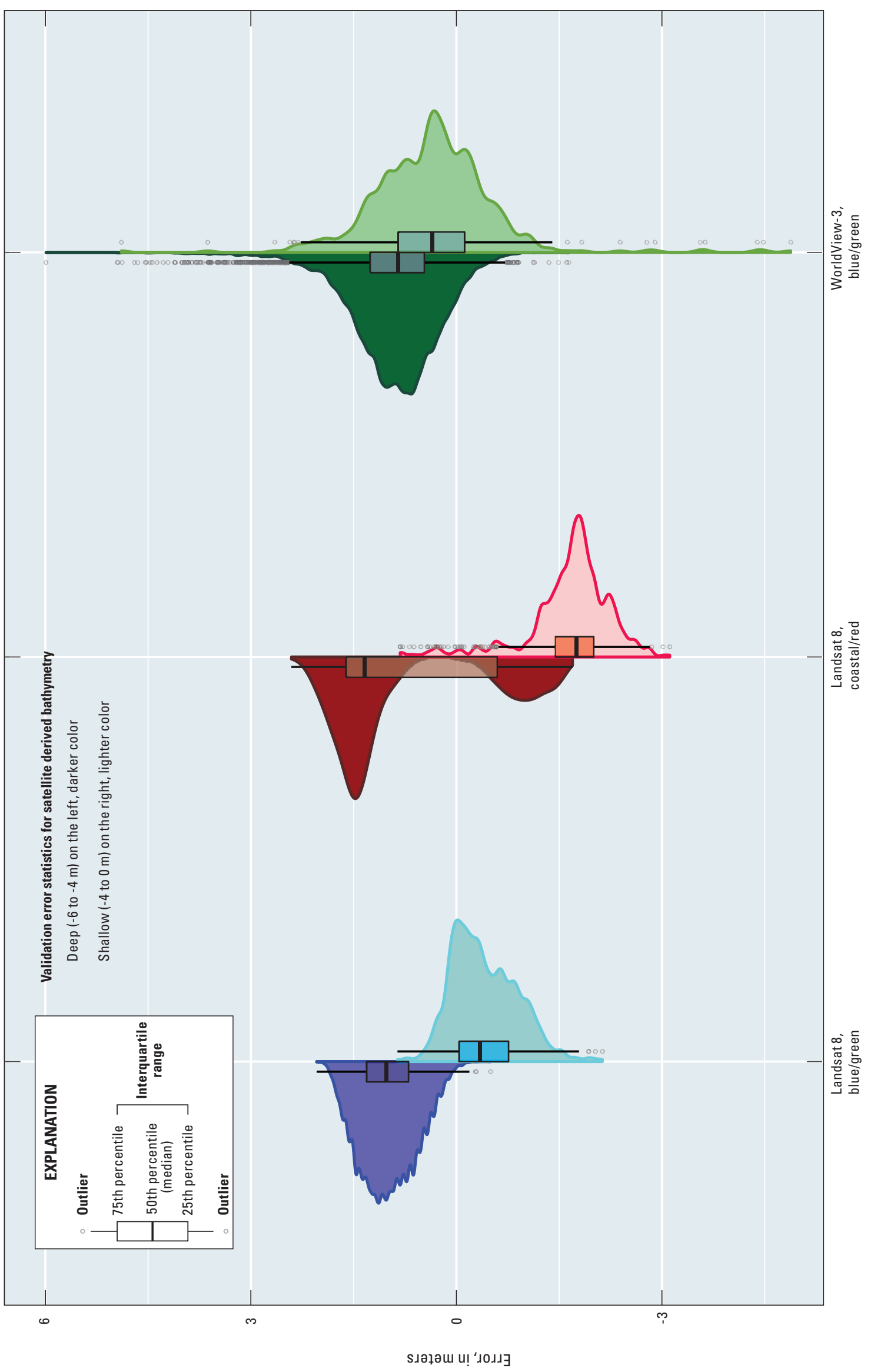

능도

응

글

힝응

空芯导

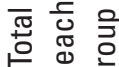

음 묻음

훙

(1) $\frac{0}{5}$

흥 홓

긍 등

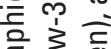

苛造

흥

交言亲

范

总焉

0 。

壱

웅

通

후을

类

도응

क 닌

可

Ф)

$\subseteq \infty \cong$

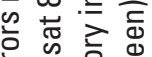

흔 学

ธ

음

응 d

음은 듬

की 든

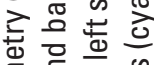

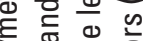

홓응

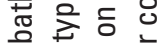

욜 总

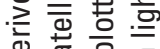

응 空

d흐를

등

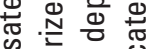

o흐잉

당

정요

的电果

흠 焉 응 흥

흥

등을 응 흔

묭

क茓菅

吅立 व

닌 뚱ㅎㅇ흥

혼돈흐. 오 
platform. A depth-related adjustment may be used to overcome the bias; however, from the SDB results, it is not clear if the adjustment would be only depth dependent or if the adjustment would be location dependent as well. For this reason, the SDB data were not further amended before integration into the Majuro, Republic of the Marshall Islands, TBDEM (fig. 5).

\section{Discussion}

There are numerous factors to consider when analyzing the bias that was evident in the SDB accuracy assessment compared to the CHARTS bathymetric lidar data. Although Stumpf and others (2003) indicated high spatial resolution, such as WV-3 imagery, is required to derive SDB because of the relatively small horizontal spatial scales in remote coral atoll locations, Lee (2012) indicated that a high off-nadir acquisition angle of WorldView imagery may contribute to derived depth errors because more off-nadir view angles proved to have lower correlation values to the actual "true" bathymetry data. Although the WV-3 imagery was collected at an off-nadir angle, the L8 imagery was collected at nadir; therefore, the off-nadir angle may not contribute to the errors in the L8 SDB. Cloud cover will affect ocean optics, thus leaving void spaces in the SDB profile estimates; however, all the L8 and WV-3 satellite images used in this research were cloud free.

Atmospheric conditions are another concern when deriving SDB. The WV-3 imagery that was atmospherically corrected was obtained from DigitalGlobe (2016). However, the accuracy assessment between WV-3-derived SDB and CHARTS bathymetric lidar data indicated a slightly higher RMSE $(1.112 \mathrm{~m})$ than the L8 blue/green band ratio $(1.065 \mathrm{~m})$, although the overall mean error for WV-3 SDB was slightly lower $(0.867 \mathrm{~m})$ than the $\mathrm{L} 8$ blue/green ratio $(0.947 \mathrm{~m})$ (table 1). Several scientific publications have presented questions about the advantage of using atmospherically corrected imagery when attempting to describe the variability of optical water properties because the atmospheric corrections may pose unnecessary bias in accurately assessing the spatial models because of cumulative increase in error uncertainty (Goodman and others, 2008; Kutser, 2012; Monteys and others, 2015). Additionally, Harris Geospatial Solutions (2017) (developer of the ENVI software) recommends when using their relative water depth tool, which is based on Stumpf and others (2003), it is typically best to not perform atmospheric correction. Atmospheric correction of littoral or marine areas often alters the data such that calculating water depths may produce anomalous and unsatisfactory results (Harris Geospatial Solutions, 2017).

The ratio of natural logarithms approach depends on ancillary geospatial data, such as multibeam echo sounder or bathymetric lidar, to calibrate relative SDB profile estimates to absolute depths. For this research, the L8 and WV-3 imagery that was used to derive SDB was acquired in 2016. The
CHARTS bathymetric lidar data that were used to calibrate relative SDB depths were acquired in 2006, a 10-year temporal span. Although single- and multibeam soundings were available from NGA for SDB calibration, some depths were collected as far back as 1944 (National Geospatial-Intelligence Agency Maritime Safety Office, 2011; 2017). Some of the older soundings may be viable for SDB calibration in more stable locations; however, the Majuro Atoll near-shore zone is an area of high wave energy and dynamics that make it prone to bathymetric change with time. Therefore, it was important to use the most recent and best available CHARTS bathymetric lidar data (Naval Oceanographic Office, 2006a; 2006b) for SDB calibration purposes in the Majuro Atoll, Republic of the Marshall Islands.

The lack of high-resolution coastal TBDEMs has been identified as a critical data gap required for flood, storm surge, hurricane, and sea-level rise inundation hazard zones for atoll nations (Helweg and others, 2014; Palaseanu-Lovejoy and others, 2017b). To fill this need, the CoNED Applications Project created an integrated 1-m TBDEM for the Majuro Atoll, Republic of the Marshall Islands, that consists of the best available multisource topographic and bathymetric elevation data for onshore and offshore areas (fig. 5) (Danielson and others, 2016; Palaseanu-Lovejoy and others, 2017b; Thatcher and others, 2016).

The Majuro Atoll TBDEM integrates nine different data sources:

- Structure from motion (SfM) (Palaseanu-Lovejoy and others, 2017b)

- Unmanned aircraft systems (UAS) imagery (more than 35,000 images collected - the largest SfM UAS collection in the western Pacific) (Palaseanu-Lovejoy and others, 2017a; 2017b)

- Real-time kinematic Global Navigation Satellite Survey survey points (Palaseanu-Lovejoy and others, 2017a; 2017b)

- USGS L8 imagery (U.S. Geological Survey, 2016b)

- DigitalGlobe WV-3 imagery (DigitalGlobe, 2016)

- SDB vertical profile estimates (Palaseanu-Lovejoy and others, 2017b; this publication)

- South Pacific Applied Geoscience Commission (SOPAC) bathymetry (Kruger and Kumar, 2008)

- Hydrographic surveys, single-beam acoustic surveys, and multibeam acoustic surveys obtained for SDB calibration purpose from NGA (National Geospatial-Intelligence Agency Maritime Safety Office, 2011; 2017)

- The U.S. Naval Oceanographic Office CHARTS bathymetric lidar data (2006a; 2006b). 

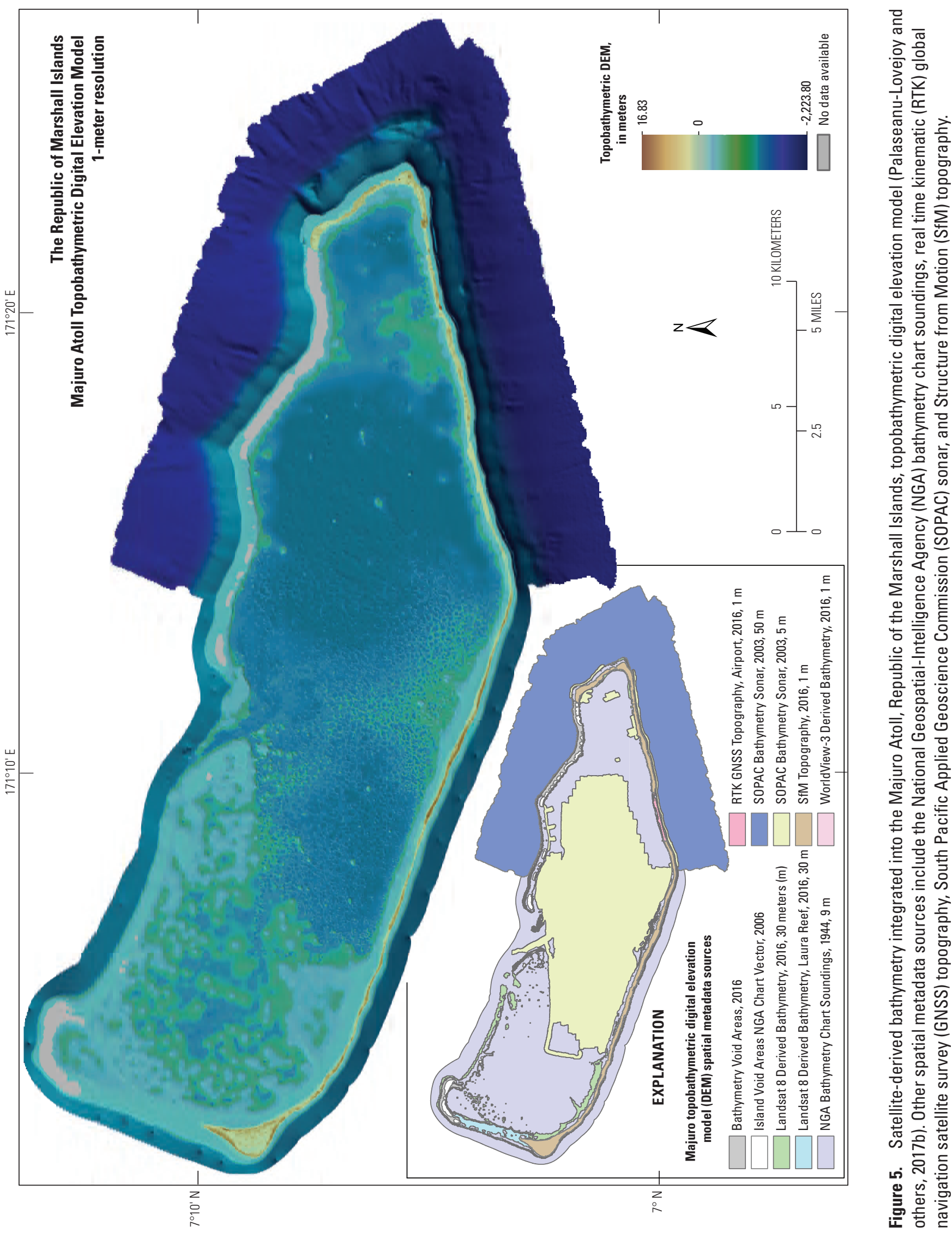


\section{Conclusion}

Low-lying coral atolls, such as the Majuro Atoll, Republic of the Marshall Islands, are subject to natural hazards, such as flooding, exceptionally high tides, hurricanes, and sea-level rise. Considering that the highest natural elevation on the atoll is only $3 \mathrm{~m}$ above sea level, the lack of high-resolution topobathymetric data has been identified as a critical data gap for climate vulnerability and adaptation efforts and for high-resolution inundation modeling for atoll nations. Active sensors, such as light detection and ranging (lidar) or sound navigation and ranging (sonar), have been used to collect bathymetric data; however, green laser lidar acquisitions aboard a small fixed-wing aircraft are challenging because of the costs associated with mapping remote Pacific islands. Ships collecting soundings cannot operate safely while navigating close to the shore; therefore, remote sensing research that uses ocean optics to estimate near-shore bathymetry using passive multispectral satellite imagery, such as Landsat 8 (L8) or DigitalGlobe WorldView-3 (WV-3), has become a more cost-effective means for mapping near-shore bathymetry to assess vulnerability to natural hazards in low-lying atolls in the northern tropical Pacific. This study is one of the first attempts to use satellite-derived bathymetry (SDB) for shallow near-shore bathymetry in the context of a tropical carbonate platform.

The most common method for deriving SDB from passive satellite imagery is the band ratio-based technique, commonly called the natural logarithm approach, in the International Hydrographic Organization Intergovernmental Oceanographic Commission General Bathymetric Chart of the Oceans Cook Book. The purpose of the SDB research was to apply the band ratio technique to L8 at-sensor radiance imagery and WV-3 atmospherically corrected imagery to characterize the attenuation of light within the water column in the coastal waters surrounding the Majuro Atoll, Republic of the Marshall Islands. Attenuation coefficients were applied to relative vertical profile bathymetric estimates that were calibrated to Compact Hydrographic Airborne Rapid Total Survey (CHARTS) bathymetric lidar data collected by the U.S. Navy and received from the Naval Oceanographic Office.

The CHARTS bathymetric lidar data yielded a strong linear relation with water depths. The L8 SDB blue/green band ratio exhibited a water attenuation extinction depth of $6 \mathrm{~m}$ with an $R^{2}=0.9324$; estimates derived from the coastal/ red band ratio had an $R^{2}=0.9597$. At the same extinction depth, SDB estimates derived from WV-3 imagery exhibited an $R^{2}=0.9574$. Accuracy assessments were completed for SDB using the CHARTS bathymetric lidar data, which indicated a positive bias of $0.947 \mathrm{~m}$ for the L8 blue/green band ratio, $0.285 \mathrm{~m}$ for the $\mathrm{L} 8 \mathrm{coastal} / \mathrm{red}$ band ratio, and $0.867 \mathrm{~m}$ for the WV-3 derived bathymetry. It is unclear if the positive bias was because of the water conditions (waves, tide, or water clarity), errors introduced by the instrument or mode of deployment, atmospheric conditions, or off-nadir angle of the high-resolution imagery. Therefore, additional investigations were completed based on depth intervals for overall errors, 0-4 m errors, and 4-6 m errors (6-m extinction depth). The L8-derived bathymetry exhibited a bimodal distribution, whereas the WV-3 derived bathymetry was positively biased for both depth intervals.

Additional information regarding the CoNED Applications Project is available at the USGS Coastal Changes and Impacts website at https://topotools.cr.usgs.gov/ and the CoNED Applications Project website at https://topotools. cr.usgs.gov/coned/.

\section{References Cited}

Danielson, J.J., Poppenga, S.K., Brock, J.C., Evans, G.A., Tyler, D.J., Gesch, D.B., Thatcher, C.A., and Barras, J.A., 2016, Topobathymetric elevation model development using a new methodology - Coastal National Elevation Database: Journal of Coastal Research, no. SI 76, p. 75-89. [Also available at https://doi.org/10.2112/SI76-008.]

Dierssen, H.M., Zimmerman, R.C., Leathers, R.A., Downes, T.V., and Davis, C.O., 2003, Ocean color remote sensing of seagrass and bathymetry in the Bahamas Banks by highresolution airborne imagery: Limnology and Oceanography, v. 48, no. 1, p. 444-455. [Also available at https://doi. org/10.4319/1o.2003.48.1_part_2.0444.]

DigitalGlobe, 2016, WorldView-3: DigitalGlobe data sheet, 2 p., accessed January 2017 at http://satimagingcorp. s3.amazonaws.com/site/pdf/WorldView3-DS-WV3-Web. pdf.

Gesch, D.B., Brock, J.C., Parrish, C.E., Rogers, J.N., and Wright, C.W., 2016, Introduction-Special issue on advances in topobathymetric mapping, models, and applications: Journal of Coastal Research, no. SI 76, p. 1-3. [Also available at https://doi.org/10.2112/SI76-001.]

Goodman, J.A., Lee, ZhongPing, and Ustin, S.L., 2008, Influence of atmospheric and sea-surface corrections on retrieval of bottom depth and reflectance using a semi-analytical model-A case study in Kaneohe Bay, Hawaii: Applied Optics, v. 47, no. 28, p. F1-F11. [Also available at https:// doi.org/10.1364/AO.47.0000F1.]

Harris Geospatial Solutions, 2017, SPEAR relative water depth: Harris Geospatial Solutions web page, accessed August 28, 2017, at https://www.harrisgeospatial.com/docs/ SPEARRelativeWaterDepth.html.

Helweg, D.A., Nash, S.A.B., and Polhemus, D.A., 2014, The Pacific Islands Climate Science Center five-year science agenda, 2014-2018: U.S. Geological Survey Open-File Report 2014-1075, 30 p. [Also available at https://doi. org/10.3133/ofr20141075.] 
Hintze, J.L., and Nelson, R.D., 1998, Violin plots-A box plot-density trace synergism: The American Statistician, v. 52, no. 2, p. 181-184. [Also available at https://doi.org/10.1 080/00031305.1998.10480559.]

International Hydrographic Organization, Intergovernmental Oceanographic Commission, 2016, The IHO-IOC GEBCO cook book: IHO Publication B-11, IOC Manuals and Guides 63: Monaco and France, International Hydrographic Organization, 429 p., accessed December 2016 at https:// www.star.nesdis.noaa.gov/sod/lsa/GEBCO_Cookbook/.

Kruger, J., and Kumar, S., 2008, High-resolution bathymetric survey of Majuro, Republic of Marshall Islands: EU EDF 9-SOPAC Project Report 117, Pacific Islands Applied Geoscience Commission, Suva, Fiji, 39 p., 2 charts.

Kutser, Tiit, 2012, The possibility of using the Landsat image archive for monitoring long time trends in coloured dissolved organic matter concentration in lake waters: Remote Sensing of Environment, v. 123, p. 334-338, accessed August 2017 at https://doi.org/10.1016/j.rse.2012.04.004.

Lee, K.R., 2012, Using multi-angle WorldView-2 imagery to determine ocean depth near Oahu, Hawaii: Monterey, Calif., Naval Postgraduate School, master's thesis, 113 p., accessed August 31, 2017, at https://calhoun.nps. edu/bitstream/handle/10945/17399/12Sep_Lee_Krista. pdf? sequence $=1 \&$ isAllowed $=\mathrm{y}$.

Legleiter, C.J., and Overstreet, B.T., 2012, Mapping gravel bed river bathymetry from space: Journal of Geophysical Research-Earth Surface, v. 117, no. F4, article number F04024. [Also available at https://doi. org/10.1029/2012JF002539.]

Monteys, Xavier, Harris, Paul, Caloca, Silvia, and Cahalane, Conor, 2015, Spatial prediction of coastal bathymetry based on multispectral satellite imagery and multibeam data: Remote Sensing, v. 7, no. 10, p. 13782-13806. [Also available at https://doi.org/10.3390/rs71013782.]

National Geospatial-Intelligence Agency Maritime Safety Office, 2011, North Pacific Ocean Republic of the Marshall Island Majuro Atoll chart 81782: U.S. Navy surveys of 1944 and 2006, 3d ed., NGA Maritime Operation.

National Geospatial-Intelligence Agency Maritime Safety Office, 2017, North Pacific Ocean Republic of the Marshall Island Majuro Atoll digital nautical chart 12 vector product format: U.S. Navy surveys of 1944 and 2006, 3d ed., NGA Maritime Operation at https://dnc.nga.mil/DNC/Chart01. php?chart=12.

National Institute of Standards and Technology, 2015, Violin plot: National Institute of Standards and Technology web page, accessed September 5, 2017, at http://www.itl.nist. gov/div898/software/dataplot/refman1/auxillar/violplot.htm.
Naval Oceanographic Office, 2006a, Data processing report: Republic of the Marshall Islands (RMI) archive number 06H3A03, survey dates 22 April-1 May, 2006, updated October 12, 2006.

Naval Oceanographic Office, 2006b, Report of survey: Republic of the Marshall Islands (RMI) archive number 06H3A03, survey dates 22 April-1 May, 2006, updated September 19, 2006.

Palaseanu-Lovejoy, M., Danielson, J.J., Gesch, D.B., Kottermair, M., Jalandoni, A., Barbee, M., Carlson, E., and Thatcher, C.A., 2017a, Improving elevation mapping in the Pacific; Majuro Atoll, RMI-1-meter DEM Project [poster], presentation at Federal Unmanned Aircraft Systems (UAS) Workshop, NASA Ames Research Center, Mountain View, Calif., 28-30 March 2017: U.S. Geological Survey.

Palaseanu-Lovejoy, M., Poppenga, S.K., Danielson, J.J., Tyler, D.J., Gesch, D.B., Kottermair, M., Jalandoni, A., Carlson, E., Thatcher, C., and Barbee, M., 2017b, One meter topobathymetric digital elevation model for Majuro Atoll, Republic of the Marshall Islands, 1944 to 2016: U.S. Geological Survey data release, at https://doi.org/10.5066/ F7416VXX.

Pe'eri, S., Madore, B., Alexander, L., Parrish, C., Armstrong, A., Azuike, C., and Tetteh, E., 2016a, LANDSAT 8 satellitederived bathymetry, chap. 11 in The IHO-IOC GEBCO Cook Book, IHO Publication B-11, IOC Manuals and Guides 63: Monaco and France, International Hydrographic Organization, p. 243-304, accessed December 2016 at https://www.star.nesdis.noaa.gov/sod/lsa/GEBCO_Cookbook/.

Pe'eri, Shachak, Madore, Brian, Nyberg, John, Snyder, Leland, Parrish, Christopher, and Smith, Shep, 2016b, Identifying bathymetric differences over Alaska's North Slope using a satellite-derived bathymetry multi-temporal approach: Journal of Coastal Research, no. SI 76, p. 56-63, accessed May 2016 at https://doi.org/10.2112/SI76-006.

Pe'eri, Shachak, Parrish, Christopher, Azuike, Chukwuma, Alexander, Lee, and Armstrong, Andrew, 2014, Satellite remote sensing as a reconnaissance tool for assessing nautical chart adequacy and completeness: Marine Geodesy, v. 37, no. 3, p. 293-314. [Also available at https://doi.org/10.1 080/01490419.2014.902880.]

Stumpf, R.P., Holderied, Kristine, and Sinclair, Mark, 2003, Determination of water depth with high-resolution satellite imagery over variable bottom types: Limnology and Oceanography, v. 48, no. 1, p. 547-556, at https://doi.org/10.4319/ lo.2003.48.1_part_2.0547. 
Thatcher, C.A., Brock, J.C., Danielson, J.J., Poppenga, S.K., Gesch, D.B., Palaseanu-Lovejoy, M.E., Barras, J.A., Evans, G.A., and Gibbs, A.E., 2016, Creating a Coastal National Elevation Database (CoNED) for science and conservation applications: Journal of Coastal Research, no. SI 76, p. 64-74. [Also available at https://doi.org/10.2112/SI76-007.]

U.S. Geological Survey, 2016a, Landsat-Earth observation satellites (ver. 1.1, August 2016): U.S. Geological Survey Fact Sheet 2015-3081, 4 p., accessed December 2015 at https://doi.org/10.3133/fs20153081.

U.S. Geological Survey, 2016b, Landsat 8 multispectral imagery, March 1, 2016: U.S. Geological Survey EarthExplorer web page, accessed July 7, 2017, at https://earthexplorer. usgs.gov.

For more information about this publication, contact

Director, USGS Earth Resources Observation and Science Center

47914 252nd Street

Sioux Falls, SD 57198

(605) 594-6151

For additional information visit https://eros.usgs.gov

Publishing support provided by the

Rolla Publishing Service Center 

